\title{
The comparison between the market value (MVA) the net profit after tax by economic value added (EVA) to net profit after tax of the companies listed on the in Tehran Stock Exchange
}

\author{
Saleh Payande Ashtiani ${ }^{1}$, Amir Rahimi Ashtiani ${ }^{2}$ \\ 1 The financial Assistance Branch, Islamic Azad University of Ashtian Branch, reconciliation and reconciliation \\ 1Email: amirrahimi_1356@yahoo.com \\ 2 Master of Accountancy, Islamic Azad University of Ashtian Branch. \\ 2Email: ps.payandeh@yahoo.com
}

\begin{abstract}
Desired performance and eventually increase the company's value will increase shareholder wealth. The fundamental challenge of managing businesses to create value for shareholders. The comparison between the market value (MVA) the net profit after tax by economic value added (EVA) to net profit after tax of the companies listed on the in Tehran Stock Exchange in 2007 to 2014. So that can be a benchmark internal performance evaluation that a representative of the market value is also achieved which the statistical was determined technique of a linear regression coefficient, And EVIEWS and SPSS software was used to test the hypotheses. The results show that there are positive correlation between (MVA/EARING) as the dependent variable (EVA/EARING) as independent variables studied in all companies, regardless of their weakness. So the companies listed in in Tehran Stock Exchange (EVA/EARING) as a measure of internal performance measurement alone is not enough to predict the effectiveness criteria is value in the market. In our group of companies and industries except, automotive and pharmaceutical industries that there were not a significant relationship between the variables in the rest of the industry significant relationship between the variables.
\end{abstract}

\section{Key words}

Economic value added, market value added, earnings, cost of capital, in Tehran Stock Exchange.

\section{Introduction}

Today, most analysts believe, that companies must ensure the cost of capital and equipment according to the value, In this respect what revisions are needed to test and validate methods to the appropriate resources and optimal allocation of capital devote in their the economy and satisfy the people. In this research we the relationship between the value of listed companies in Tehran Stock Exchange in a period of economic Bhardar and value in the accounting period in selected companies in the in Tehran Stock Exchange data is calculated technique. In this research to be included the economic performance criteria of the refined economic value added and market value added [1]. With the development of capital markets is reflected in the criteria for evaluating the performance of companies through their existing content is also highlighted. The competition between the two categories of traditional and value-based performance evaluation criteria in order to justify the company's researchers, in evaluating the performance of the traditional method is only due to accounting profit. And because the cost of capital is not considered desirable method no one of the criteria is economic value added the guidance provides managers to evaluate performance of business units and capital markets can also be used to benefited from evaluate business units. Based on the economic value when value is created which the business units are able to cover all their operating costs and capital expenditures and value-added remains as well as economic benefit. The market value of the index class wealth creation for shareholders, under the impact of the economic value is judged. Theoretically the value of a company at a given date function of capital market expectations with respect of economic value in future years [3].

\section{Theoretical Foundations}

What is clear brand positioning in the global competition in the years to come will be very complicated? Managers must be able to gain control and planning and changes in the environment, the best way of providing capital creates resources and maximize wealth for investors and shareholders [2].

Measure the performance of business leaders assess the economic value-added evaluation. Performance evaluation and decision-making be used in investment management. Assessment of business performance manager may not be achievable and although prices may not reflect the true value of their stock market capitalization [4]. It is possible that the difference between the actual stock value and the actual price, if economic value is very similar to traditional accounting earnings measures, there is the main difference in addressing the overall cost of capital and economic value, while talking traditional accounting for the increase in costs (non-operating costs) is not the cost of equity. If the capital cost estimation is a subjective process, performance criteria such costs cannot be ignored reveal a company's success and the difference between the economic value accounting and how this disagreement arising from the reward to shareholder rights, the main difference is in addressing the overall cost of capital and economic value, while talking traditional accounting for the increase in costs (non-operating costs) is not the cost of equity. If the capital cost estimation is a subjective process performance measures, such costs cannot be ignored reveal a company's success, the difference is in the creation of shareholder value, the difference between the economic values and how traditional accounting is in disagreement with generally accepted accounting principles [7]. The refusal of rewards equity accounting for reforms value added performance benefits as well as economic, companies interested in obtaining high yields average cost of capital rates that are prone to create positive EVA. An added value of the stock sales led to a deficit that caused it. If a company is always a balanced return of capital costs, and its market value remains at zero, despite how much of that has increased activity. 
Companies that how to potentially identify and exploitation consumer will not cause are worth nothing alot of projects and they cannot return equivalent to the cost of capital or the minimum amount to earn the most noteworthy, the performance evaluation criteria is based on the historical performance [5]. One of the most useful performance evaluation criteria as well as economic value added measure is anticipated shareholder value. Company management plans to maximize shareholder wealth based on economic value added, unfortunately, many companies produce profits without taking into account the opportunity cost of capital on their own. Not only solution to this problem provides maximum economic value but is also closely associated with the net present value. Economic Value Added with the theory that a measure of economic value added, which represents the actual performance ratio is projected to decrease or increase performance. Positive economic value means that the company's value, taking into account increased the cost of capital employed [6]. EVA Performance measurement method is suitable for the purposes of assessment strategies, capital allocation, designing reward systems, increase investment and pricing, The capital increase and the pricing is economic value added as an evaluation criterion economic forecast with other measures such as increasing cash, Cash-seekers shareholders and the market value of the investments are consistent, finally, as a measure of economic value added accounting function is less susceptible distortion to calculate the economic value can be used the following equation [8]:

EVA $=(r-c)^{*}$ capital

$E V A=N O P A T-\left(W^{*} C^{*}\right.$ capital $\left.t-1\right)$

One of the most useful performance evaluation criteria as well as economic value added measure is anticipated shareholder value, company management plans to maximize shareholder wealth based on economic value added, unfortunately, many companies ultimate benefit of their products regardless of their capital cost estimate and opportunities. Max not only provides a solution to this problem but also to maximize shareholder wealth often have incentives that are created in managers. An economic Value Added is also closely associated with the net present value. An economic Value Added with the theory that the value of the company only in projects with positive net present value increases compatible. Economic Value Added is a measure that reflects the actual performance decrease or increase compared to the performance predicted. Positive Economic Value Added means the value of the company by taking used increased the cost of capital. An economic Value Added Performance measurement method is suitable for the purposes of evaluating asset allocation strategies designed reward systems raise capital and pricing is Economic Value Added as an evaluation criterion with other criteria such as economic performance, anticipated cash value added shareholder value and once the investment is consistent current cash, Finally, as a measure of economic value added accounting function is less susceptible distortion [7-10].

To calculate the Economic Value Added can be of approaches and measures performance evaluation:

A) Accounting approach: In this approach are used, the figures in the financial statements, such as, selling, profits, return on assets, return on equity shares.

B) Economic approach: In this approach is used, the economic concepts,

Business unit performance with emphasis on profitability of the company's assets and according to the rate of return and the rate of cost of capital used is evaluated. Of the value of this approach can be cited intensified economic. Economic Value Added by multiplying the difference between the rate of return and the rate of cost of capital (C) obtained in the amount of capital.

$\mathrm{EVA}=(\mathrm{r}-\mathrm{c})^{*}$ capital

\section{Added valued principles}

Added value is defined in economic literature by Rogers, Svjan the company as a business unit or center defines a decision for shareholders that the entity will follow the same theory, In this case the role of accounting is to provide reports till in this way different parts can result interested and happened to have a better understanding of a company during a financial period. Svjan concept of added value as revenue in measurement and evaluation, a management tool for use in accounting due to the different groups interested in information suggested. He believes that the value added to the income statement and provides balance sheet for more information for consumers. It has caused that, He is the first author of the concept of added value recognized in accounting [9].

\section{A review of previous research}

Stewart rated six hundred and thirteen thousand in 1991 company of top American, In terms of Economic Value Added during 1987 and 1988 Average rating, the study divided them into 25 groups based on the average Economic Value Added and market value for each of the 25 groups based on their changes. The result was that in companies with positive Economic Value Added, high correlation between these two measures, there are also changes mean. (Coefficient of determination. /. 97), while companies with a negative Economic Value Added, not very interesting correlation between these two measures.

Roodposhti Guide: (2007) evaluated the economic value-added functions and market value added to assess economic performance in a five-year period in industries and listed on the Stock Exchange reviews. The results show that there are between EVA with financial variables studied, such as EPS, ROI, also been confirmed relationship between KVA with ROS and the results show that the relationship between the variables EVA compared with MVA with more variables. 


\section{Conclusion and Recommendations}

In the present study measured the relationship between ratings in the economic field in the accounting measurement between the MVA and the analysis ROE, and then the relationship between MVA and EVA and ROA as well as Pearson's correlation is calculated REVA. The statute refers to the relationship between KVA and ROA where Pearson's correlation coefficient was 700. /, and this relationship was positive and the signal value or smaller is rejected than 5 . /Bvd so $\mathrm{HO}$. MVA and ROE have a linear relationship between the variables in the second to fifth hypothesis such as, ROE, EPS, REVA MVA represents that are the Pearson's correlation coefficient with the dependent variables, respectively 599./,662./,832./, The current value is less than 5\%, indicating that the above hypothesis $\mathrm{H} 0$ is rejected for all relationships, and a significant positive relationship between the two variables. In companies listed on the in Tehran Stock Exchange Economic Value Added to earnings as a measure of internal performance measurement alone is not enough to predict the effectiveness criteria is value in the market and the results show, investors in their investment decisions do not pay much attention to the benchmark internal performance. The results indicate that the in Tehran Stock Exchange index and the traditional systems which to date have used new measures to evaluate the performance of their greater efficiency, According to the results of a poor connection domestic index value (Economic Value Added), with index value (Market added value ), It is recommended that investors in making investment decisions, while attention to the value of domestic businesses, which is measured by Economic Value Added accounting information and pay other performance evaluation criteria. The final results of the Group companies surveyed, it can be stated that there are the correlation between economic data and value added and market-based approaches which the logical connection in the car industry and parts manufacturing in the pharmaceutical industry, but this does not seem logical connection. The results obtained in this study, a total of surveyed companies are in full compliance with the results obtained by Fernandez.

\section{REFERENCES}

1. Maryam Abadin (2006), the impact of Economic Value Added and profitability of the stock market value of the car industry and parts manufacturing companies listed in in Tehran Stock Exchange, MS Thesis, and University of Mazandaran.

2. Ahmad Pur, Ahmad and Ghodrat alah Bazegar, attitude and activity-based costing system and Economic Value Added.

3. Ahmad pour, Ahmad and Mahmod Yahya zadeh far, (Financial Management), the first volume of Mazandaran University.

4. Anvari and Rostami with their co-worker (2004), the relationship between the Economic Value Added of the interest tax profit, cash flow from operating activities by stock market value of companies listed on in Tehran Stock Exchange.

5. Ezad nia, Nasar (2003), Assessment of business units using the Economic Value Added of Allameh Tabatabai University.

6. Rodposti guide, Fereydon (2010), Assessment of the performance Economic Value Added and market value added to assess economic performance.

7. Serazi, Hasan (2005), the relationship between Economic Value Added tax cash flow operating activities Earnings before interest and stock market value listed in in Tehran Stock Exchange. Master's thesis and Tarbiat Modarres University.

8. Shirin Bakhsh Shams alah and Zahra Hasan khansari, (2011), Eviews econometrics in the application of Tehran. Research Institute Economic Affairs.

9. Zahiri Mohammad, (2010), the relationship between Economic Value Added and earnings per share of stock with a market value of companies listed in in Tehran Stock Exchange.

10. Norush Eraj and Bita Mashayekhi (2004), the usefulness of accounting earnings forecast value added in manufacturing firms listed in in Tehran Stock Exchange from 1996 to 2002. 